\title{
The Influence of Pod Casts and Social Media in Elt
}

\author{
Avinash.M
}

\begin{abstract}
The rapid growth of the Software companies and the high standard of living enjoyed by the Software professionals has undeniably sprouted up the quest for learning English. Most students rush to private institutes to gain proficiency in English Language. Hence there is a dire need for the teachers to modernize their teaching techniques. Text books, black board teaching, passive listening should be ceased and there should be technological teaching tool in every English teaching classroom. This paper aims to introduce the modern teaching tools used in many countries to our Indian teachers. Social Networks are very popular in Teaching English but in India social networks end up its reach being a personal interactive tool. This paper cites various instances where Social Networks, pod casts, twitters, blogs etc., play a vital role in teaching English. This paper aims to discuss the success rate before and after the intervention of Technology in classrooms. It also analyses the cause for the success of such teaching tools. When an English teacher decides to implement a new methodology in teaching English then this paper would undoubtedly serve as a guide in using Social Networks and other technological tools in his teaching.

( key words: modernize, modern teaching tools, interactive tool, Social Networks, pod casts, twitters, blogs)
\end{abstract}

\section{Introduction:}

Heterogeneousness and assimilation power are the two basic characteristics of English language and as a result English language continues to enjoy the privilege of the most sought language of this Universe. Everywhere communication in English is vividly sought. Most of the English teachers complain that insipid syllabus, poor parenting, lack of interest and frequent diversions among the learners are few factors that affect second language acquisition, on the other hand, most learners complain that inefficient teaching tools and methods have made them so. However, it is undeniable for them the complexities of the language also stand as a hindrance. Grammar translation method, Direct method are few successful methods adopted earlier but it is a known fact that in this fast moving world and technological era outdated methods have no role to play, which results in demanding a modern methodology that suits both the teacher and the learner.

\section{Podcasts:}

Pod casting democratizes the world of Radio. It is a service where the listener culls out an audio lesson of English language and listens on audio digital players preferable an i-pod. The files are in Mp3 or mp4 format. It is a transfer of audio files at free of cost which not even demands an ipod for listening the lessons. The learner sends back the feedback preferably his queries to the teacher and in turn this transfer of files has connected the listener or the learner with his mentor. Really simple Syndication (RSS) feed, helps to download these files and when it allows to save the file to the listener's personal computer. It is also recorded information and hence the learner learns his lessons whenever he feels comfortable. A major drawback in learning an English lesson is the lack of interest, the distance and mode of transport the learner uses, his emotions and passions, environment all these factors prevent him from being attentive but when we consider pod casting method of sending lessons it helps the learner to have repeated sessions. He gets direct attention from the teacher which is not possible in an Indian classroom situation. The teacher can also test his previous knowledge, understanding of the content; he makes his lessons clearly for he is not stressed in making an attentive classroom. This would undoubtedly provide a healthy relationship between the learner and the teacher and would serve as an supply of content. Some say this new technology is democratizing the once corporate-run world of radio innovative methodology for teaching and language acquisition.

\section{ESL-EFL podcasts:}

Breaking News English podcast features 546+ mp3s, ESL-Library- mini podcasts for English learners, English Club, My American Friend, A cup of English, Absolutely Intercultural, English, Better China 232, Connect Learning, Education Podcasts, Ello, ELT Podcasts, ESL Culips, ESl Podcasts, ESL podcasts (Shumbles), ESLpod, Intelligenic, Learn English (Elementary),Learn English: Podcasts, Learn English: professional English, Learn-Out-Loud, Listen to English, Moving at the Speed of Creativity Podcasts, National Capital Language Resource Center, The Business Spotlight Podcast, The English Desk, Viewpoint ,VOA Special English Podcast, Voice of America: Learning English, Word Nerds, Word2Word are some of the reputed podcasts that helps English teachers and learners. All Things Considered, BBC podcasts, Canada Podcasts, Car 
Talk, CBC Podcasts, Cool Podcasts, Deutsche Welle, Digital Podcast, ESL Teacher Talk, Fresh Air, Itunes, My Podcast, National Public Radio (NPR), The Diane Rehm Show, The New York Times Podcasts, Voice of America: News are generally claimed as the authentic podcasts.

\section{Blogs:}

Blogs are a kind of pages written by an author to exhibit his ideas. Edu blogs are most sought in these days and grammar lessons for second language acquisition is made easy through these blogs, "Historically, a weblog, or 'blog' for short, is recognized by its regularly updated, time and date stamped posts, running down the computer screen in chronologically reverse order (i.e. the most recent post comes first). Crucially, there is an 'Add Comment' feature so that readers of posts can leave their opinions, questions or thoughts. Finally, there is a writing style element: blogs are written by one individual who gives his or her thoughts in a generally relaxed, 'spoken' style" McIntosh (2005) (p. 2). Through Blogs an English teacher expresses his views and conducts tests and the learner gets the material supplied by the teacher and learning takes place continuously despite of the distance of both the teacher and listener. It is a convenient mode of teaching “...'Blogs' have evolved along similar lines to other forms of human communication in that they are a product of convenience rather than design" Williams \& Jacobs (2004), (p. 232).

Every day lessons are recorded here for future references, "like a journal, a blog can be a continually updated resource that grows over time with the accumulation of writing and other content. This archived information is accessed using a simple calendar that highlights the dates on which entries were made" Lamshed, Berry, \& Armstrong (2002) (p. 9). These and various other researchers (Hiler, 2003; Thorne \& Payne, 2005) have also recognized blogging as "a set of... phenomena" that has, since its inception as a manner of producing anything from online diaries to academic and reflective journals, emerged to have the capacity to "engage people in collaborative activity, knowledge of sharing, reflection and debate" (Williams \& Jacobs, 2004, p. 232). "Is not uncommon, over a period time, for a distinctive style to emerge, in the course of writing entries and responding to feedback, that reflects the personal character of the blog's creator... "Significantly, rather than alienate a readership by exposing one's personal traits and idiosyncrasies, this adds to the very popularity of a blog" (Williams \& Jacobs, 2004, (p. 235).

\section{Blogs and Sites that are widely acclaimed for ESL / EFL trainers:}

\section{T.I.R.F.}

The mission of The International Research Foundation for English Language Education is to generate new knowledge about English language teaching and learning.

ELT Global Blog:

ELT Global Blog is the English Language Teaching blog run by Oxford University Press. The blog is aimed at ELT teachers and trainers, or anyone else interested in the world of ELT.

Pros Write

Pros Write is devoted to better workplace writing -- without platitudes. This blog is used to talk about writing in English for professionals of all kinds, focusing on teachers.

ELT Training

If you are thinking about training to be an English teacher, if you are doing a CELTA or Cert TESOL course or if you have just started teaching, www.elt-training.com is ideal for you!

(Almost) Infinite ELT Ideas

This is a highly original and interesting blog, although it's more of an ideas factory than a blog, packed with lesson ideas for ESL teachers.

Joyful collapse

This interesting blog, written by Mindy Keller-Kyriiakides, seeks to help teachers - high school English educators - in determining best practices for reaching today's adolescents.

English Attack!

The English Attack! Entertainment English Blog explains and discusses various approaches in teaching English to EFL and ESL learners, in particular teens and young adults.

EFL Training

Written by an experienced ESL teacher and teacher trainer, this blog is written for teachers and trainee teachers who are passionate about teaching and interested in lifelong learning.

Views from the Whiteboard

A great site for EFL teachers to pick up ideas and activities to use in their classroom, run by Teresa, an English teacher based in San Fernando, in the south of Spain.

Ken Wilson's Blog

Ken Wilson is a teacher trainer, an author of ELT materials and until 2002, artistic director of the English Teaching Theatre.This is his blog, and it's highly recomended. 
Burcu Akyol's blog

Burcu Akyol's blog contains reflections and insights about teaching, technology, and life \& practical tips and resources. It's an interesting blog as well as a pretty one.

Jeremy Harmer's Blog

Written by Jeremy Harmer, a writer and teacher / teacher-trainer for ESL, this blog is about teaching.

Matt Bury's Blog

Matt's blog, dedicated to topics related to Second Language Acquisition, learning and teaching theory, elearning, CALL, elearning software and systems development.

\section{FACE BOOKS}

Face books have become an integral part of young people today. Hence English teaching through face book is very successful in countries like The USA and China; Most of our Indian universities magnify the disadvantage that arises out of social networks. Most of them claim that the learner will get distracted very easily and the motif of the lesson plan could be lost, but this disadvantage prevails in almost all methods of teaching and hence it is a novel idea for most of English teachers to bring their learners in one group. A teacher can create a group in face book and make it public to make all his interested learners to become a part of it. Competitions can be conducted which could improve the writing skills of the learners. Inviting guests / learners, uploading ample examples, videos pertaining to the topic, using wall to encourage them, discussion boards that allows even the slow learner in a class to come out of his queries without any sort of fear

In most Indian classroom the listener is passive. He fails to respond or hesitates to respond. This problem will not arise teaching through face books. Teacher gets ample time and learning becomes ease and interesting.

Tweeter teachers created by Tara Benwell vividly expresses the benefits of using tweets for Teaching English, "Twitter is a great networking site for TEFL. You can use twitter to: look for jobs, meet other teachers, post links to your blog, share links to TEFL articles, share links to online lessons, write and read teacher tips, stay connected to your favourite sites, learn other languages, get inspiration for your classes, keep in touch with your friends and teachers even when you are away from your institution”.

\section{Conclusion:}

Most Indian classrooms have inadequate facilities, insufficient teachers and a drastic classroom strength and it is evident that all the above mentioned tools and methods cannot be implemented all of a sudden for most of the learners are first generation learners and are completely new to any sort of technology, but today we have an alarming situation, all the hope is not lost yet, English teachers could equip themselves in operating these methods and performing them to their target learners. They could choose 50 of their slow learners and could try teaching them through these methods. This would undoubtedly result in success and with the help of the management more such operations could be performed. Most teachers prefer delivering their goods / lecture is the sole motive of the entrance into the classroom and they fail to motivate the young learners to be technically strong people. Content and methodology are the two things that need an immediate attention and Technology and social networks can alone to a great extent reduce the burden of the learners and would provide an ease education taking place in and out of the classroom.

\section{Reference:}

[1]. Hiler, J. (2002). Blogs as disruptive tech: How weblogs are flying under the radar of the content

[2]. management giants. Webcrimson.com. Retrieved on September 25, 2007, from http://www.

[3]. webcrimson.com/ourstories/blogsdisruptivetech.html

[4]. Lamshed, R., Berry, M., \& Armstrong, L. (2002). Blogs: Personal e-learning spaces. Binary Blue. Retrieved on September 29, 2007, from http://www.binaryblue.com.au/docs/blogs.pdf

[5]. McIntosh, E. (2005). From learning logs to learning blogs. Scottish Centre for Information on Language Teaching and Research. Retrieved on September 29, 2007, from http://www.scilt.stir.ac.uk/SLR/ Current\%20Issue/SLR13\%20McIntosh.pdf

[6]. Thorne, S., \& Payne, J. (2005). Evolutionary trajectories, Internet-mediated expressions, and language education. CALICO Journal, 22(3), 371-397. 